\title{
Effect of pig manure amendments on nutrient accumulation and leaching in three subtropical agricultural soils
}

\author{
Di Zhang ${ }^{1,2}$ \\ ${ }^{1}$ Nanjing Xiaozhuang University, School of Environmental Science, Nanjing, 211171, China \\ ${ }^{2}$ Key Laboratory of Soil Environment and Pollution Remediation, Institute of Soil Science, Chinese \\ Academy of Sciences, Nanjing, 210008, China \\ email: zhangdi@njxzc.edu.cn
}

\begin{abstract}
Keywords: phosphorus accumulation; nitrate leaching; application rate; soil type
Abstract. Environmental pollution due to livestock breeding with organic manure input instead of chemical fertilizers (partially or completely) has become a major concern. This study conducted six combinations of pig manure treatments $\left(25,50,100,200,400\right.$ and $\left.800 \mathrm{~kg} \mathrm{P} \mathrm{hm}^{-2}\right)$ with half of conventional chemical fertilizers, conventional fertilization (CF) and an unfertilized control (CK) to investigate the impact of different manure applications on nutrient accumulation and leaching in a peanut-radish cropping system using three soils in subtropical China. The results indicated that a higher application rate of pig manure readily led to excessive phosphorus accumulation in soils and polluted shallow groundwater by nitrate leaching. The leaching risk in the three soils decreased in the following order: granite>sandstone >red clay, and the degree of nutrient accumulation increased in the following order: granite<sandstone<red clay. Environmental risk may occur when the pig manure application rate was over $200 \mathrm{~kg} \mathrm{P} \mathrm{hm}^{-2}$ in three soils.
\end{abstract}

\section{Introduction}

Pig manure is an important organic source of nutrients and can recycle nutrients in the crop-livestock production system to preserve the environment and increase soil quality (Singh et al., 2010). Especially, conventional intensive agriculture has been characterized by a high input of chemical fertilizers, leading to deteriorating soil quality due to reductions in soil organic matter (Liu et al., 2009). With regards to soil degradation due to the excessive application of chemical fertilizers and the environmental pollution caused by poultry and livestock breeding, organic manure input instead of chemical fertilizers (partially or completely) has become a major concern (Mandal et al., 2007). Numerous studies have demonstrated the potential of pig manure to act as fertilizer due to its high nutrient content while also noting potential undesirable environmental concerns such as the excessive accumulation of nutrients (Ghosh et al., 2010). Therefore, the objectives of this study were to investigate nutrient accumulation and leaching after different quantities of manure were applied to the three soils in southern China and to search for safe application rate of pig manure for this system.

\section{Materials and Methods}

The experiment was conducted at the Ecological Experimental Station of Red Soil, Chinese Academy of Soil Science in Yujiang County, Jiangxi Province $\left(28^{\circ} 15.20^{\prime} \mathrm{N}, 116^{\circ} 55.30^{\prime} \mathrm{E}\right)$. This research site is characterized by a typical subtropical humid monsoon climate with an annual air temperature ranging from $17.7^{\circ} \mathrm{C}$ to $40^{\circ} \mathrm{C}$ and a mean annual rainfall of $1754 \mathrm{~mm}$, nearly $50 \%$ of rainfall is from March to June (Zhang et al. 2015).

Three dominating upland soils in subtropical China (red clay, sandstone and granite soils) were collected to fill plastic buckets $(55 \mathrm{~cm}$, height and $34 \mathrm{~cm}$, diameter) according to the original layers in the field, respectively. The initial soil properties were listed in Table 1. The fertilization experiment was performed in eight treatments with three replicates per treatment, the annual application rates of pig manure were 25 (P25), 50 (P50), 100 (P100), 200 (P200), 400 (P400) and 800 (P800) kg P hm², with half of the local conventional chemical fertilization rate $\left(\mathrm{N}: 50 \mathrm{~kg} \mathrm{hm}^{-2}, \mathrm{P}: 25 \mathrm{~kg} \mathrm{hm}^{-2} ; \mathrm{K}: 50 \mathrm{~kg}\right.$ $\mathrm{hm}^{-2}$ ). Chemical fertilizer application at the local conventional fertilization rate was termed "CF". 
The control treatment " $\mathrm{CK}$ " had no allochthonous organic amendments or chemical fertilizers. The pig manure was collected from pig farms near the experimental station and had an average total phosphorus of $12.6 \mathrm{~g} \mathrm{~kg}^{-1}$, total nitrogen of $28.8 \mathrm{~g} \mathrm{~kg}^{-1}$, total carbon of $304.5 \mathrm{~g} \mathrm{~kg}^{-1}$ (dry matter basis) and water content of $69 \%$.

Peanut-radish (Arachis hypogaea L.-Raphanus sativus L.) rotations were conducted during this experiment, and peanuts were sown in the early of April and harvested in the middle of August. Radish, as a catch crop, was then sown in the beginning of September and harvested in the beginning of December (Zhang et al. 2015).

Table 1. Physical and chemical properties of the surface soils $(0-20 \mathrm{~cm})$

\begin{tabular}{ccccccc}
\hline Soil type & $\begin{array}{c}\mathrm{pH} \\
(2.5: 1)\end{array}$ & $\begin{array}{c}\text { Organic } \\
\mathrm{C}\left(\mathrm{g} \mathrm{kg}^{-1}\right)\end{array}$ & $\begin{array}{c}\text { Available N } \\
\left(\mathrm{mg} \mathrm{kg}^{-1}\right)\end{array}$ & $\begin{array}{c}\text { Available } \\
\mathrm{P}\left(\mathrm{mg} \mathrm{kg}^{-1}\right)\end{array}$ & $\begin{array}{c}\text { Silt } \\
(0.002-0.02 \mathrm{~m} \\
\mathrm{m})(\%)\end{array}$ & $\begin{array}{c}\text { Clay } \\
(<0.002 \mathrm{~mm}) \\
(\%)\end{array}$ \\
\hline Red clay & 4.64 & 5.16 & 59.50 & 28.34 & 20.68 & 45.92 \\
Sandstone & 4.51 & 2.82 & 48.50 & 5.82 & 7.88 & 15.44 \\
Granite & 5.44 & 3.92 & 58.48 & 20.40 & 11.61 & 6.79 \\
\hline
\end{tabular}

Leachate samples were mixed as one analysis sample every ten days during the rainy season (from April to July) according to the leachate volume ratio during each precipitation event. The samples were stored in a refrigerator $\left(4^{\circ} \mathrm{C}\right)$ prior to analysis. After harvesting the radishes, topsoil $(0-20 \mathrm{~cm}$ depth) samples from all treatments were collected to analyze the available nitrogen and phosphorus.

The means $(n=3)$ and standard deviations (S.D.) of the nitrate and total phosphorus concentrations and available nutrients are presented. The significant differences among the fertilization treatments were assessed using a one-way ANOVA followed by the LSD test at a 5\% probability level.

\section{Results}

\section{Nitrate and phosphorus concentrations in the leachate}

During the rainy season, the nitrate concentrations varied widely with fertilization in the three soils (Fig. 1). The nitrate concentration significantly increased when the pig manure amount exceeded 100 $\mathrm{kg} \mathrm{P} \mathrm{hm}{ }^{-2}$ in the red clay soil and $800 \mathrm{~kg} \mathrm{P} \mathrm{hm}^{-2}$ in the sandstone and granite soils. In the granite and sandstone soils, the nitrate concentrations with the chemical fertilizer treatment $(\mathrm{CF})$ exceeded or were approximately similar to the maximum contaminant value $\left(20 \mathrm{mg} \mathrm{L}^{-1}\right.$; groundwater quality standard for Class III). When the pig manure dosage reached $400 \mathrm{~kg} \mathrm{P} \mathrm{hm}^{-2}$, the nitrate concentrations were all greater than $20 \mathrm{mg} \mathrm{L}^{-1}$. The phosphorus concentrations were lower than $0.02 \mathrm{mg} \mathrm{L}^{-1}$ (surface water quality standard for Class I in China) with almost all fertilization treatments, except for the conventional fertilizer treatment (CF) and the $800 \mathrm{~kg} \mathrm{P} \mathrm{hm}^{-2}$ pig manure treatment in the granite soil.

$\square \mathrm{CK} \square \mathrm{CF} \square \mathrm{P} 25 \square \mathrm{P} 50 \sqsubseteq \mathrm{P} 100 \rightleftarrows \mathrm{P} 200 \square \mathrm{P} 400 \square \mathrm{P} 800$
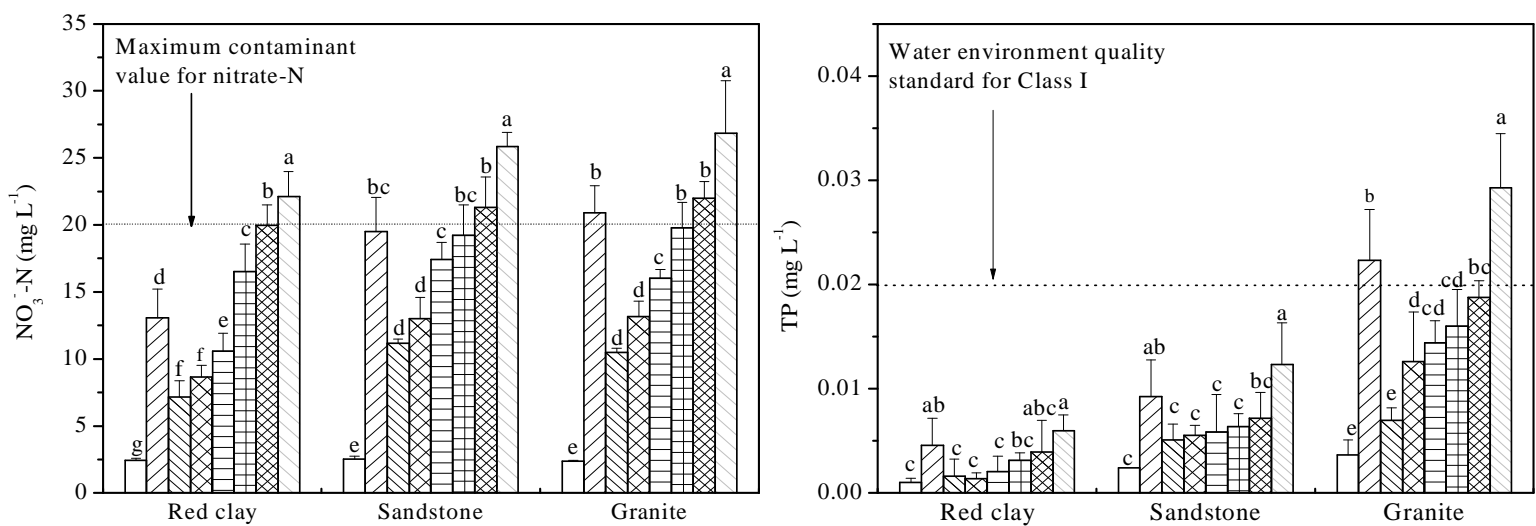

Fig. 1 Average nitrate and total phosphorus concentrations in the leachate from different soils in rainy season (April to July) 


\section{Available nutrient accumulation in the soils}

Rapidly available soil nutrients were significantly related to manure fertilization and the soil type. Although the available soil $\mathrm{N}$ increased with the pig manure dosage, the values for the pig manure treatments were below $70 \mathrm{mg} \mathrm{kg}^{-1}$ for the granite soil, $80 \mathrm{mg} \mathrm{kg}^{-1}$ for the sandstone soil and $100 \mathrm{mg}$ $\mathrm{kg}^{-1}$ for the red clay soil, which were all still at a lower grade (Fig. 2). However, unlike the available N, the available $\mathrm{P}(\mathrm{AP})$ increased dramatically in the high pig manure dosage treatment, and the highest amount of AP was close to $170 \mathrm{mg} \mathrm{kg}^{-1}$ in the red clay soil. The content was significantly higher in the red clay soil compared to the other soils, and the AP already exceeded $40 \mathrm{mg} \mathrm{kg}^{-1}$ for the P200 treatment in the red clay, the P400 treatment in the sandstone soil and the P800 treatment in the granite soil.

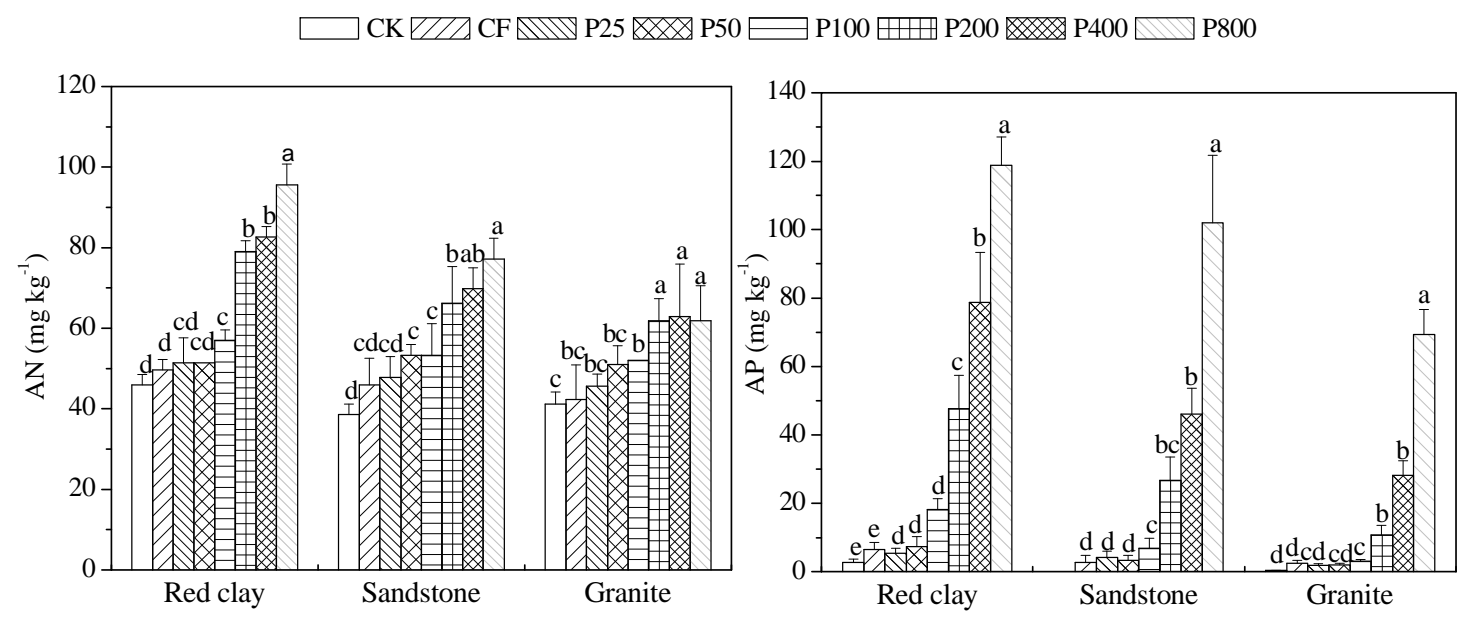

Fig.2 Effects of fertilization on available nitrogen and phosphorus in three soils

\section{Discussion}

For $\mathrm{P}$, it is hard to leach vertically, because soil particles react intensely with $\mathrm{P}$ making it hard for transport in soils (Wang et al. 2011). Unlike $\mathrm{P}$, most $\mathrm{N}$ is in the form of $\mathrm{NO}_{3}{ }^{-} \mathrm{N}$, which is transformed by $\mathrm{NH}_{4}{ }^{+}-\mathrm{N}$ through nitrification, rapidly increasing the $\mathrm{NO}_{3}{ }^{-} \mathrm{N}$ concentration in the soil. If not taken up by the crops, $\mathrm{NO}_{3}{ }^{-} \mathrm{N}$ may be transferred into the soil sublayer profile by the leachate solution and even leach out of the soil into natural waters (Girotto et al. 2013). In this study, the effects of manure application on nitrate leaching were much greater than those on phosphorus leaching; however, the accumulation of available phosphorus in the soil was far easier. This finding has also been verified by Wang et al. (2011), who demonstrated that only a small portion of $\mathrm{P}$ was found in the leachate samples. According to a previous study, excessive $\mathrm{P}$ accumulation with fertilizer treatments may induce phosphorus losses through runoff. McDowell and Sharpley (2001) indicate that it is easy to lose $\mathrm{P}$ in a silt loam soil with Olsen-P over $36 \mathrm{mg} \mathrm{kg}^{-1}$ due to runoff. In addition, Ashjaei et al. (2010) report that $\mathrm{NaHCO}_{3}-\mathrm{P}$ exceeded $40 \mathrm{mg} \mathrm{kg}^{-1}$, indicating a significant threshold effect of labile soil $\mathrm{P}$ on leaching in acidic, sandy soils.

The accumulation of phosphorus in the red clay soil was much higher than in the sandstone and granite soil, and nitrate leaching decreased in the following order: granite>sandstone>red clay soil, indicating that the red clay soil had a stronger nutrient preserving capability compared to the other two soils and also demonstrating that the nutrient accumulation and leaching were related to the soil texture. The red clay soil showed a higher clay content (Table 1), resulting in a higher phosphorus fixation ability. This observation is in agreement with Olson et al. (2010), who found that less P was retained in the upper soil profile of a coarse textured soil than a more fine textured soil. The nitrate in the sandstone and granite soil was more easily leached compared to the red clay soil. With higher clay contents in red clay soils (Table 1), slower water movement and a lack of oxygen in pores may reduce nitrogen nitrification and the mineralization of organic nitrogen, thus decreasing nitrate leaching (Griffin et al. 2002). 


\section{Conclusions}

Appropriate amounts of pig manure integrated with chemical fertilizer may improve soil nutrients compared to the use of only chemical fertilizer in the three soils. With regards to water environment protection, pig manure dosages should be no more than $400 \mathrm{~kg} \mathrm{P} \mathrm{hm}^{-2}$ in red clay soils and $200 \mathrm{~kg} \mathrm{P} \mathrm{hm}^{-2}$ in sandstone and granite soils. For P accumulation, the pig manure dosage should be no more than $200 \mathrm{~kg} \mathrm{P} \mathrm{hm}^{-2}$ in red clay soils and $400 \mathrm{~kg} \mathrm{P} \mathrm{hm}^{-2}$ in sandstone and granite soils. Further verification studies using long-term field experiments will be required before these results can be widely applied to field production.

\section{Acknowledgements}

This research was supported by the Natural Science Research Project for Colleges and Universities of Jiangsu Province, China (16KJB610010).

\section{References}

[1] S. Ashjaei, H. Tiessen, J.J. Schoenau. Correlations between phosphorus fractions and total leachate phosphorus from cattle manure-and swine manure-amended soil. Commun. Soil Sci. Plan. Vol. 41(2010), p. 1338-1349

[2] S. Ghosh, P. Lockwood, H. Daniel, et al. Short-term effects of organic amendments on properties of a Vertisol. Waste Manag. Res. Vol. 28 (2010), p. 1087-1095

[3] E. Girotto, C.A. Ceretta, C.R. Lourenzi, et al. Nutrient transfers by leaching in a no-tillage system through soil treated with repeated pig slurry applications. Nutr. Cycl. Agroecosyst. Vol. 95 (2013), p. 115-131

[4] T.S. Griffin, C.W. Honeycutt and Z. He. Effects of temperature, soil water status, and soil type on swine slurry nitrogen transformations. Biol. Fert. Soils Vol. 36 (2002), p. 442-446

[5] M.Q. Liu, F. Hu, X.Y. Chen, et al. Organic amendments with reduced chemical fertilizer promote soil microbial development and nutrient availability in a subtropical paddy field: The influence of quantity, type and application time of organic amendments. Appl. Soil Ecol. Vol. 42 (2009), p. 166-175

[6] A. Mandal, A.K. Patra, D. Singh, et al. Effect of long term application of manure and fertilizer on biological and biochemical activities in soil during crop development stages. Bioresource Technol. Vol. 98 (2007), p. 3585-3592

[7] R.W. McDowell, Sharpley A.N. Variation of phosphorus leached from Pennsylvanian soils amended with manures, composts or inorganic fertilizer. Agric. Ecosyst. Environ. Vol. 102 (2004), p.17-27

[8] B.M. Olson, E. Bremer, R.H. McKenzie, et al. Phosphorus accumulation and leaching in two irrigated soils with incremental rates of cattle manure. Can. J. Soil Sci. Vol. 90 (2010), p. $355-362$

[9] J.S. Singh, D.P. Singh, A.K. Kashyap, et al. Microbial biomass C, N and P in disturbed dry tropical forest soils, India. Pedosphere. Vol. 20 (2010), p. 780-788

[10] L.Q. Wang, T. Liang, Z.Y. Chong, et al. Effects of soil type on leaching and runoff transport of rare earth elements and phosphorous in laboratory experiments. Environ. Sci. Pollut. Res. Vol. 18 (2011), p. 38-45

[11] D. Zhang, Xiaogang L., Xingxiang W. Accumulation of Soil Available Phosphorus under Pig Manure Application Limits Microbial Community Function in Upland Soils. Int. J. Agric. Biol.17(2015), p. 17: 929-946 